\title{
PERFORMANCE AND SOME RUMEN AND BLOOD PARAMETERS OF BALADI COWS FED RATIONS CHECKED SUPPLEMENTED WITH PRODUCTIVE CHAMOMILE FLOWERS DURING LATE PREGNANCY AND TurnitIn LACTATING PERIODS. \\ El-Kholany, M. E. ;A.A. Mehany; G. A, Maged and \\ A. A. El-Mowafy. \\ Animal Production Research Institute, Agricultural \\ Research Center, Dokki, Giza, Egypt
}

\section{ABSTRACT}

This research was conducted to evaluate effects of two levels of chamomile flowers to the rations of baladi cows on their milk production, feed conversion and feeding values as well as some rumen and blood parameters. A total of 18 cows with average live body weight of $401.00 \mathrm{~kg}$ and 2-7 parities, were used in this study. Animals were divided into three groups ( 6 in each group) and fed diets according to NRC (1988) recommendation that contained 0, 5 and $10 \mathrm{~g}$ chamomile / $100 \mathrm{~kg} \mathrm{BW} \mathrm{/}$ day. The animals were in the late pregnancy period and continued for 4 months after calving. In addition, 9 Zaraibi bucks were used to evaluate the feeding values of the tested rations, and some rumen liquor parameters .

The results showed that the digestion coefficients of all nutrients and feeding values were improved with increasing the level of chamomile $(0,5$ and $10 \mathrm{~g} / 100 \mathrm{~kg}$ BW / day) in the rations $\left(G_{1}, G_{2}\right.$ and $G_{3}$, respectively) and the differences were significantly in digestibility of DM, CF and CP as well as TDN and DCP \%. The results of rumen parameters of Zaraibi bucks showed that $\mathrm{pH}$ value and ammonia- $\mathrm{N}$ were not significantly different among the groups. But, addition of chamomile had significantly increased total volatile fatty acids (TVFA's) concentrations at $4 \mathrm{hr}$ post-feeding in rumen fluied of bucks. The highest values of protozoa count and microbial protein at 4 hr were recorded with $\mathrm{G}_{3}(0.840$ and 0.685 , respectively) and the lowest values were recorded with $\mathrm{G}_{1}$ ( 0.770 and 0.580 , respectively).

Concerning biochemical parameters, the results indicated that most tested constituents of blood were not significantly affected by the tested experimental rations during the late pregnancy and lactation periods. Serum globulin was increased while $\mathrm{ALT}$ enzyme were reduced as a result of adding chamomile especially with the high level $\left(\mathrm{G}_{3}\right)$.

Daily milk yield was increased by 5.81 and $9.42 \%$ for $\mathrm{G}_{2}(9.10 \mathrm{~kg})$ and $\mathrm{G}_{3}$ $(9.41 \mathrm{~kg})$ compared with the control $(8.60 \mathrm{~kg})$. However, milk composition was not significantly affected by both of the two levels of chamomile. But, yields of fat and protein as $g / d$ were significantly increased $(p<0.05)$ by the high chamomile level.

The feed conversion based on DM was improved by about 6.0 and $8.5 \%$ as a result of using chamomile in $G_{2}$ and $G_{3}$, respectively compared to $G_{1}$. A similar trend was noticed when feed efficiency was based on TDN where the best was $G_{3}$ ( 0.752 ) followed by $\mathrm{G}_{2}$ ( 0.767 ) and lowest the control group ( 0.794$)$.

Accordingly, it could be concluded that using chamomile in baladi cows rations had positive effects not only in improving milk yield, but also in improving feed utilization without any adverse effects on milk composition and blood metabolic parameters.

Keywords : Productive performance -lactating cow - some rumen and blood parameters - chamomile flowers - milk production - feeding value- feed conversion. 


\section{INTRODUCTION}

The use of medicinal herbs and plants for human has been well known since the old civilization of ancient Egyptian. Many attempts were carried out to use natural materials such as medicinal herbs which are widely accepted as feed additives to improve the efficiency of feed utilization and productive performance of farm animals such as sheep, goats, buffaloes and cows ( Allam et al. 1999, Maged 2004, Shehata et al. 2007 and Shwereb, 2012). In addition, using medicinal herbs in animal rations was the preventive solution to avoid the hazard of side effects using chemicals. Row material of these herbs and their extracts and drugs proved to be always safe ( Zeid, 1998, Tawfik et al. 2005, and Maged 2011). In the meantime, using medicinal herbs as natural additives in animal feeding for various proposes such as improvement of the milk yield and its composition and consequently improving milk quality (Shehata et al. 2004), improving the ruminal fluid environment and digestion coefficients as well as reducing the cholesterol and improve some the enzymes activity ( ALT, AST and ALP) in the blood (Maged 2004, and 2011), reducing the incidence of digestive disturbances such as diarrhea and bloat and consequently minimizing the mortality rate of the offspring (Shehata et al. 2007), improvement of immunity and detoxification of the afflatoxin ( Tawfik et al. 2005). Consequently they are used in both human and veterinary medicines.

Shehata et al., (2004 and 2007) studied the effect of using chamomile flowers on production and hygiene of goat milk and they concluded that adding chamomile flower has positive effect on milk production and its quality and general animal performance as well. These positive effects might be attributed to active ingredients like flavonoids, coumarins, aromatic oils (alpha bisabolol, azulene and chamazulene) in chamomile flowers that function as better tonic, antiseptic, stomach pain release, anti-inflammatory and antispasmodic agent( Mann and Staba, 1986, Korting et al., 1993 and Ody Penelope, 1993).

Therefore, the present study was conducted to evaluate effects of chamomile flowers on digestibility, feeding values and milk production as well as feed utilization efficiency some rumen parameters and blood constituents as affected by dietary treatments were also studied.

\section{MATERIALS AND METHODS}

This study was carried out during 2014-2015 at El-Serw Experimental Station belonging to the Animal Production Research Institute, Agriculture Research Center, Egypt.

Animals:

A total of 18 Baladi cows during their last two months of pregnancy, with an average live body weight of $401 \pm 20.15 \mathrm{~kg}$ and $2^{\text {nd }}$ to $7^{\text {th }}$ parities, were used in this study. The experimental cows were divided according to LBW, parity and milk production to three experimental groups, six animals in 
each group. The three groups were assigned at random to receive the three dietary treatments. Animals were housed under semi-open shed.

Feeding system:

During pre-and 4 months post-partum period, cows in all groups were fed diet composed concentrate feed mixture (CFM), and berseem hay $(\mathrm{BH})$, while rice straw (RS) was offered ad lib. The CFM consisted of $27 \%$ wheat bran, $41 \%$ yellow corn, $26 \%$ uncorticated cotton seed meal, $4 \%$ molasses, $1.5 \%$ premix and $0.5 \%$ common salt. Chemical analysis of CFM, BH and RS are shown in Table (1).

Table (1): Chemical analysis of feed ingredients ( $\%$ as fed basis).

\begin{tabular}{|l|c|c|c|c|c|c|c|}
\hline Feed stuffs & DM & OM & CP & CF & EE & Ash & NFE \\
\hline Concentrate feed mixture & 93.47 & 90.34 & 14.71 & 16.88 & 3.53 & 8.34 & 56.54 \\
\hline Berseem hay & 91.34 & 85.52 & 13.67 & 24.31 & 2.67 & 15.26 & 44.09 \\
\hline Rice straw & 90.19 & 82.60 & 2.49 & 40.59 & 1.93 & 17.25 & 37.74 \\
\hline
\end{tabular}

Cows in the 1st group were fed the control diet( untreated), while those in the 2nd and 3rd groups were fed the control diet supplemented daily with 5 or $10 \mathrm{~g}$ of chamomile flowers / $100 \mathrm{~kg} \mathrm{BW}$, respectively. Supplements of each treatment group were well mixed with the ingredients of the daily amount of CFM immediately before feeding. Feeds were offered to animals in all groups twice daily for 2 months pre- and 4 months post-partum period. Cows in all groups were individually fed on different experimental diets and water was individually offered three time/ day with daily recording of water consumption.

Cows in the 3 groups were fed based on body weight milk yield and fat percentage according to (NRC,1988). Amount of feeds were adjusted biweekly based on milk yield and reproductive status.

Milking and milk samples :

Milk yield was measured after the calves were allowed to suckle colostrums from their dams for the first seven days. Cows were milked by milking machine twice daily at 5 a.m. and 5 p.m. After each milking, milk was weighed on certain day for each week for all lactation periods. Milk composite samples of each animals ( mixture from morning and evening milking) were taken during mid-lactation period for the determination of milk composition.

\section{Blood sample :}

Blood samples were taken once during the last month of pregnancy and first month of lactation from 3 cows of each group. Blood serum samples were separated by centrifugation at $4000 \mathrm{rpm}$ for 10 minutes, then frozen at -20c until analysis for total protein, albumin, globulin, urea, creatinine, total lipids, AST and ALT using kits and the methods reported by biochemistry (Bio merieux) laboratory reagents and products.

Digestion and rumen fluid parameters :

Three digestibility trials were conducted on 9 adult bucks (3 per group) to evaluate feeding values of the tested diets. Each digestibility trail lasted 35 days, of which four weeks were preliminary period followed by 7 days collection period. 
At the end of digestibility trails rumen fluid samples were taken from bucks using stomach tube before feeding ( 0 time) and at 2, 4 and 6 hrs postfeeding. The samples were filtered through 3 layers of gauze without squeezing and immediately subjected to the determination of $\mathrm{pH}$ value by $\mathrm{pH}$ meter. Ammonia nitrogen (NH3-N ) concentration was measured according to Conway (1957), total volatile fatty acids (TVFA's) according to the technique described by Warner (1964), microbial protein by the method of Shultz and Shultz (1970) and total number of protozoa was counted according to AboAkkada and El -Shazly (1964).

Chemical analysis:

Chemical analysis of feeds and feces was determined after the Official methods of A.O. A.C (1980), while chemical analysis of milk and somatic cells was determined using milk Scan (Model 133B).

Statistical analysis:

Data was statistically analysis using SAS (2003). The significant differences among means were assigned according to Duncan (1955).

\section{RESULTS AND DISCUSSION}

\section{Digestibility trails:}

Digestion coefficients :

The obtained data in Table 2 indicated that the effect of the experimental rations on digestibility of $\mathrm{DM}, \mathrm{CF}$ and $\mathrm{CP}$ and feeding value (TDN, and DCP) were significant. Whereas, the digestibility of OM, EE and NFE were not significantly different as a result to addition of chamomile herbs in goats rations. The highest values of digestion coefficients of all nutrients were recorded with the high level of chamomile (G3) but the lowest values were detected with unsupplemented ration ( control, G1). Similarly, the TDN and DCP\% of tested diets were improved with increasing the level of chamomile in goats diets and the differences were significant between $\mathrm{G} 1$ and G3. The improvement in digestibility and feeding values with the presence of chamomile herb may be due to the role of the active ingredients that function as an antiseptic against the antagonistic flora and stimulate the digestive enzymes and processes (Abou-Zeid, 1986, Khanna et al., 1993 and Mclntyre, 1995). The results are in line with those reported by Abdelhamid et al (2004) who showed that most digestion coefficients and feeding values were higher as a result of using of chamomile flowers in diets of Rahmani sheep. 
Table (2) : Digestion coefficients and feeding values (\%) of tested diets fed to bucks.

\begin{tabular}{|l|c|c|c|}
\hline \multirow{2}{*}{ Items } & \multicolumn{3}{|c|}{ Groups } \\
\cline { 2 - 4 } & $\mathbf{G}_{1}$ & $\mathbf{G}_{2}$ & $\mathbf{G}_{3}$ \\
\hline Digestion coefficients (\%): & $67.01 \pm 0.52^{\mathrm{b}}$ & $68.3 \pm 0.03^{\mathrm{b}}$ & $70.00 \pm 0.55^{\mathrm{a}}$ \\
\hline DM & $70.30 \pm 0.44$ & $71.43 \pm 0.25$ & $72.54 \pm 0.86$ \\
\hline OM & $60.55 \pm 1.32^{\mathrm{b}}$ & $62.33 \pm 0.62^{\mathrm{ab}}$ & $64.46 \pm 0.42^{\mathrm{a}}$ \\
\hline CF & $71.55 \pm 0.39^{\mathrm{b}}$ & $73.6 \pm 0.55^{\mathrm{ab}}$ & $74.8 \pm 0.90^{\mathrm{a}}$ \\
\hline CP & $77.33 \pm 0.56$ & $78.18 \pm 0.22$ & $79.47 \pm 0.44$ \\
\hline EE & $72.89 \pm 0.42$ & $74.44 \pm 1.07$ & $75.07 \pm 0.65$ \\
\hline NFE & $67.29 \pm 0.40^{\mathrm{b}}$ & $68.82 \pm 0.48^{\mathrm{a}}$ & $69.81 \pm 0.47^{\mathrm{a}}$ \\
\hline Feeding values (\%) : & $9.29 \pm 0.08^{\mathrm{a}}$ & $9.45 \pm 0.12^{\mathrm{a}}$ \\
\hline TDN & $9.03 \pm 0.05^{\mathrm{b}}$ & 9.29 &
\end{tabular}

Means in the same row with different superscripts differ significantly at $<0.05$

\section{Rumen liquor parameters :}

Results of $\mathrm{pH}$ values $($ Table, 3$)$ indicated that maximum $\mathrm{pH}$ values were recorded at 0 time with all groups without significant differences among treatments and then gradually decreased to the minimum values at 4 hrs post feeding and tended to increase again thereafter at $6 \mathrm{hrs}$ post feeding with all groups. The same trend were observed by Zied and Ahmed (2004) with Zaraibi goats. Ruminal NH3-N concentration (Table, 3) tended to increase with G1 especially at $2 \mathrm{hrs}(23.59 \mathrm{mg} / 100 \mathrm{ml})$ compared with G2 and G3 ( 22.86 and $21.90 \mathrm{mg} / 100 \mathrm{ml}$, respectively). These observations are in harmony with the findings of Zied (1998) at most hours (0, 2 and $6 \mathrm{hrs})$. Ruminal total VFA's concentrations (m Eq/ $100 \mathrm{ml}$ ) post-feeding were increased with increasing level of chamomile in bucks diets and the differences were significant during the 4 hours only. In this respect, ruminal TVFA's concentration at $6 \mathrm{hr}$ post feeding were improved by $31.83 \%$ with chamomile treatment $(11.39 \mathrm{~m} \mathrm{Eq} / 100 \mathrm{ml})$ compared with the control diets ( $8.64 \mathrm{~m} \mathrm{Eq} / 100 \mathrm{ml}$ ) (Allam et al., 1999). In the present study, the highest values of TVFA 's concentration was at $4 \mathrm{hrs}$ post-feeding which was reflected on lowering $\mathrm{pH}$ values at that time. Similar results were given by Ahmed et al. (2001).

As regard to protozoa count and microbial protein, the obtained results indicated that both protozoa and microbial protein content were higher as a results to presence of chamomile in bucks rations ( $G 2$ and G3) but, without significant differences as shown in Table (3). Similar results were observed by Maged (2004) and Ibrahim et al. (2007) with using of chamomile and chufa tubers, respectively in diets of small ruminants. In addition, Tawfik et al. (2005) found that the content of microbial protein was improved by about $14.2 \%$ with chamomile supplemented group compared with their control and this may be attributed to the regulatory action of medicinal plant , chamomile, on NH3-N concentration in the rumen as reported by Zied (1998) and Mohamed et al., (2003) and consequently maintaining the optimal environmental for protozoa and other micro-organisms which gave high level of microbial protein synthesis in the rumen. 
Table (3) : Rumen liquor parameters of diets Zaraibi bucks fed the experimental diets.

\begin{tabular}{|c|c|c|c|c|}
\hline \multirow{2}{*}{ Items } & \multirow{2}{*}{ Hours } & \multicolumn{3}{|c|}{ Groups } \\
\hline & & $\mathbf{G}_{1}$ & $\mathbf{G}_{2}$ & $\mathbf{G}_{3}$ \\
\hline \multirow{4}{*}{$\mathrm{pH}$} & 0 & $7.07 \pm 0.08$ & $7.04 \pm 0.11$ & $7.00 \pm 0.12$ \\
\hline & 2 & $6.72 \pm 0.04$ & $6.70 \pm 0.06$ & $6.69 \pm 0.03$ \\
\hline & 4 & $6.21 \pm 0.06$ & $6.25 \pm 0.07$ & $6.21 \pm 0.09$ \\
\hline & 6 & $6.49 \pm 0.06$ & $6.50 \pm 0.07$ & $6.47 \pm 0.09$ \\
\hline \multirow{4}{*}{$\begin{array}{l}\text { Ammonia } \\
(\mathrm{mg} / 100 \mathrm{ml})\end{array}$} & 0 & $14.58 \pm 0.05$ & $15.05 \pm 0.56$ & $15.15 \pm 0.46$ \\
\hline & 2 & $23.59 \pm 0.47$ & $22.86 \pm 0.41$ & $21.90 \pm 0.17$ \\
\hline & 4 & $23.49 \pm 0.41$ & $23.27 \pm 0.72$ & $22.88 \pm 0.47$ \\
\hline & 6 & $22.49 \pm 0.6$ & $21.88 \pm 0.51$ & $21.6 \pm 0.47$ \\
\hline \multirow{4}{*}{$\begin{array}{l}\text { VFA's } \\
\text { (meq / } 100 \mathrm{ml})\end{array}$} & 0 & $8.12 \pm 0.09$ & $8.06 \pm 0.17$ & $8.22 \pm 0.51$ \\
\hline & 2 & $10.09 \pm 0.30$ & $10.26 \pm 0.14$ & $10.44 \pm 0.11$ \\
\hline & 4 & $10.78 \pm 0.09^{b}$ & $11.6 \pm 0.07^{a}$ & $11.8 \pm 0.06^{a}$ \\
\hline & 6 & $10.54 \pm 0.09$ & $10.94 \pm 01$ & $11.4 \pm 0.15$ \\
\hline \multirow{2}{*}{$\begin{array}{l}\text { Protozoa count } \\
\left(x 10^{6}\right)\end{array}$} & 0 & $0.410 \pm 0.03$ & $0.423 \pm 0.04$ & $0.435 \pm 0.02$ \\
\hline & 4 & $0.770 \pm 0.03$ & $0.835 \pm 0.02$ & $0.840 \pm 0.03$ \\
\hline \multirow{2}{*}{$\begin{array}{l}\text { Microbial protein } \\
(\mathrm{g} / 100 \mathrm{ml})\end{array}$} & 0 & $0.339 \pm 0.02$ & $0.344 \pm 0.03$ & $0.34 \pm 0.01$ \\
\hline & 4 & $0.58 \pm 0.03$ & $0.68 \pm 0.01$ & $0.685 \pm 0.02$ \\
\hline
\end{tabular}

Means in the same row with different superscripts differ significantly at $<0.05$

\section{Blood parameters :}

Data of some biochemical parameters of cows fed experimental rations during pre - and post-partum periods are presented in Table (4). The obtained data indicated that most tested blood parameters were not significantly affected by the tested experimental rations. The results indicated that both total protein and globulin tended to increase with increasing level of chamomile in cow rations and the differences were significant in serum globulin during post-partum period alone. But, serum albumin was lower with using of chamomile in cows rations during the two experimental periods, but without significant differences. Serum urea and creatinine concentrations showed some fluctuations among groups. Meanwhile, the concentrations of total lipids and the activity of AST and ALT were reduced as a result of adding chamomile in cow rations during pre- and post-partum and the effect of high level of chamomile (G3) was significant during the late pregnancy as shown in Table (4). Similar results were observed by Shehata et al. (2004), Priolo et al (2007). and Shwereb et al. (2014) with lactating does, ewes and cows, respectively. Maged (2011) reported that serum protein and globulin concentration improved while, the concentration of cholesterol and the activity of ALT and AST were decreased as a result of using some medicinal herbs in rations of dairy goats.

Generally, the obtained data showed that most serum parameters were slightly affected by chamomile, however some differences were significant but, all values within the normal range as reported by Aboul-Foutoh et al. (2011), Shwereb (2012), Zeedan and Abdel-Latif (2013) and Mostafa et al. (2014) with both lactating cows and dairy buffalos. 
Table (4) : The effect of experimental rations on some biochemical in blood serum of cows during pre-and post- partum periods.

\begin{tabular}{|c|c|c|c|}
\hline \multirow[b]{2}{*}{ Items } & \multicolumn{3}{|c|}{ Groups } \\
\hline & $\mathbf{G}_{1}$ & $\mathbf{G}_{2}$ & $\mathbf{G}_{3}$ \\
\hline \multicolumn{4}{|c|}{ During pre- partum period } \\
\hline Total protein $(\mathrm{g} / \mathrm{dl})$ & $7.14 \pm 0.08$ & $7.16 \pm 1.05$ & $7.24 \pm 0.09$ \\
\hline Albumin (g / dl) & $4.38 \pm 0.05$ & $4.24 \pm 0.03$ & $4.20 \pm 0.07$ \\
\hline Globulin (g/ dl) & $2.67 \pm 0.02$ & $2.92 \pm 0.04$ & $3.04 \pm 0.03$ \\
\hline Creatinine (mg / dl) & $0.80 \pm 0.01$ & $0.79 \pm 0.02$ & $0.81 \pm 0.01$ \\
\hline Urea $(\mathrm{mg} / \mathrm{dl})$ & $35.15 \pm 0.80$ & $35.17 \pm 0.90$ & $36.25 \pm 0.79$ \\
\hline Total lipid (mg / dl) & $365.0 \pm 10.50$ & $361.0 \pm 11.35$ & $347.0 \pm 9.93$ \\
\hline AST (u / I) & $29.35 \pm 6.30$ & $27.81 \pm 5.17$ & $26.95 \pm 7.03$ \\
\hline $\operatorname{ALT}(\mathrm{u} / \mathrm{I})$ & $7.68 \pm 1.08^{a}$ & $6.85 \pm 2.05^{\mathrm{ab}}$ & $6.29 \pm 2.30^{D}$ \\
\hline \multicolumn{4}{|c|}{ During post- partum period } \\
\hline Total protein $(\mathrm{g} / \mathrm{dl})$ & $7.25 \pm 0.07$ & $7.35 \pm 0.09$ & $7.42 \pm 0.05$ \\
\hline Albumin (g / dl) & $4.40 \pm 0.08$ & $4.27 \pm 0.11$ & $4.23 \pm 0.07$ \\
\hline Globulin $(\mathrm{g} / \mathrm{dl})$ & $2.85 \pm 0.03^{b}$ & $3.08 \pm 0.05^{\mathrm{ab}}$ & $3.19 \pm 0.06^{\mathrm{a}}$ \\
\hline Creatinine (mg / dl) & $0.71 \pm 0.02$ & $0.71 \pm 0.01$ & $0.72 \pm 0.03$ \\
\hline Urea (mg / dl) & $32.85 \pm 0.75$ & $35.03 \pm 0.63$ & $34.15 \pm 0.91$ \\
\hline Total lipid (mg / dl) & $349.0 \pm 9.52$ & $331.0 \pm 7.86$ & $325.0 \pm 8.95$ \\
\hline AST $(u / I)$ & $27.03 \pm 5.51$ & $26.11 \pm 8.05$ & $25.30 \pm 7.31$ \\
\hline $\operatorname{ALT}(u / I)$ & $6.67 \pm 2.05$ & $6.05 \pm 1.80$ & $5.80 \pm 2.30$ \\
\hline
\end{tabular}

Means in the same row with different superscripts differ significantly at $(p<0.05)$.

\section{Milk production :}

Yield of milk and all measured components (Table,5) tended to be increased by the addition of chamomile, with changes tending to be greater for the high than the low level of addition. Daily milk yield was increased by 5.81 and $9.42 \%$ for G2 and G3 compared with the control. Yields of fat and protein as $\mathrm{g} / \mathrm{h}$ were significantly increased $(p<0.05)$ by the high chamomile levels. Similar results were recorded by Shehata et al. (2004) who found that daily milk yield was increased by 6.0 and $8.9 \%$ for 5 and $10 \mathrm{~g}$ chamomile 100 $\mathrm{kg}$ BW / day, respectively comparied with the control diets. The same study indicated a positive effect on milk components such as milk fat, protein, lactose and total solids with adding chamomile rations of dairy goats during all the experimental periods ( early, mid and late lactation). Thakur et al . (2006) studied the effect of herbal feed supplementation on the performance of lactating cows and they found that daily milk and FCM yield was improved $(p<0.01)$ without affecting its composition.

In another study on milk production, Allam et al. (1999) studied the effect of using some medicinal plants and herbs as feed additives and found that daily milk yield was improved with chamomile by more than $10 \%$ compared with either the other herbs or the unsupplemented diet. The same authors reported that chamomile treatment had highest yields of milk fat, protein and total solids. Recently, Maged (2011) and Ibrahim et al. (2013) observed a positive effect of using some medicinal herbs in goats rations on total or daily milk yield during suckling and lactation periods.

Somatic cell count ( SCC) were significantly lower with G3 compared with $\mathrm{G} 1$ as shown in Table (5). The highest value of SCC was recorded with 
G1 (357000) followed by G2 (333000) and lastly the lowest value was recorded with G3 (308000). Thus, SCC was reduced by 6.72 and $13.73 \%$ for 5 and $10 \mathrm{~g}$ chamomile / $100 \mathrm{~kg} \mathrm{BW} /$ day, respectively compared with the control diet. It is interesting to note a negative relationship between SCC and milk yield ( Ahmed et al., 2008). In this respect, Baro et al. (1994) and Bedo et al. (1995) found that SCC was negatively correlated with milk yield.

Table (5) : Effect of level of chamomile supplementation on average daily milk yield and its constituents.

\begin{tabular}{|c|c|c|c|}
\hline \multirow[b]{2}{*}{ Items } & \multicolumn{3}{|c|}{ Groups } \\
\hline & $\mathbf{G}_{1}$ & $\mathbf{G}_{2}$ & $\mathbf{G}_{3}$ \\
\hline Average daily milk yield $(\mathrm{kg})$ & $8.60 \pm 0.75$ & $9.10 \pm 0.63$ & $9.41 \pm 0.69$ \\
\hline \multicolumn{4}{|l|}{ Milk composition (\%) : } \\
\hline Fat & $3.10 \pm 0.18$ & $3.17 \pm 0.16$ & $3.24 \pm 0.15$ \\
\hline Protein & $3.05 \pm 0.10$ & $3.09 \pm 0.13$ & $3.19 \pm 0.13$ \\
\hline Lactose & $4.26 \pm 0.12$ & $4.34 \pm 0.09$ & $4.42 \pm 0.11$ \\
\hline Solids non fat & $8.02 \pm 0.14$ & $8.16 \pm 0.13$ & $8.34 \pm 0.11$ \\
\hline Total solids & $11.12 \pm 0.13$ & $11.33 \pm 0.15$ & $11.58 \pm 0.20$ \\
\hline Ash & $0.71 \pm 0.002$ & $0.73 \pm 0.003$ & $0.73 \pm 0.005$ \\
\hline Somatic cell count (SCC) $\times 10^{3}$ & $357 \pm 14.0$ & $333 \pm 11.0$ & $308 \pm 9.0$ \\
\hline Av. fat yield, g/d & $266.0 \pm 11.30^{b}$ & $288.0 \pm 9.53^{\text {ab }}$ & $304.0 \pm 7.91^{\mathrm{a}}$ \\
\hline Av. protein yield, $\mathrm{g} / \mathrm{d}$ & $266.0 \pm 8.15^{b}$ & $281.0 \pm 10.20$ ab & $301.0 \pm 6.85^{\mathrm{a}}$ \\
\hline
\end{tabular}

\section{Live body weight :}

The live body weights of cows ( Table, 6) indicated non significant LBW differences among the studied groups during the two experimental periods ( late pregnancy and lactation ). Similar results were observed by Shehata et al. (2007) and Mostafa et al. (2014) using chamomile and probiotics in rations of dairy animals ( dairy goats and cows, respectively) during the late pregnancy and early lactation.

Table (6): Live body weight (LBW) of Baladi cows fed chamomile supplemented rations.

\begin{tabular}{|l|c|c|c|}
\hline \multirow{2}{*}{ Items } & \multicolumn{3}{|c|}{ Groups } \\
\cline { 2 - 4 } & $\mathbf{G}_{\mathbf{1}}$ & $\mathbf{G}_{\mathbf{2}}$ & $\mathbf{G}_{\mathbf{3}}$ \\
\hline Average LBW of cows (kg): & 401 & 405 & 397 \\
\hline Two months pre-partum & 415 & 417 & 413 \\
\hline One month pre-partum & 461 & 467 & 459 \\
\hline At calving & 405 & 403 & 397 \\
\hline Post-calving & 411 & 407 & 402 \\
\hline One month post-partum
\end{tabular}

\section{Feed intake :}

The average daily feed intake of Baladi cows during the two experimental periods ( pre and post-partum) are presented in Table (7). Cows consumed approximately similar quantity of DM intake as $\mathrm{g} / \mathrm{head} \%$ of BW and $\mathrm{g} / \mathrm{kg}$ w0.75 since all cows had similar body weight and produced mearly the same quality of milk. Comparing pregnancy and early lactation periods in the daily feed intake, the results indicated that DM intake decreased in late 
pregnancy than in early lactation period (Table, 7). This may be attributed to the increased rumen size of the animals after parturition and being free of the growed uterus stress on the rumen. It may also be attributed to the higher requirements for milk production during early lactation period. Similar results were reported by Maged (2011) and Ahmed and El-Kholany (2012) and Mostafa et al. (2014) with lactating cows and dairy goats during the late pregnancy and early lactation periods.

Table ( 7 ) : Effect of the tested experimental rations on daily feed intake of cows during pre and post-partum periods.

\begin{tabular}{|c|c|c|c|}
\hline \multirow{2}{*}{ Items } & \multicolumn{3}{|c|}{ Groups } \\
\hline & $\mathbf{G}_{1}$ & $\mathbf{G}_{2}$ & $\mathbf{G}_{3}$ \\
\hline \multicolumn{4}{|l|}{ During pre-partum period: } \\
\hline CFM (kg / h) & 4.15 & 4.15 & 4.15 \\
\hline $\mathrm{BH}(\mathrm{kg} / \mathrm{h})$ & 2.10 & 2.10 & 2.10 \\
\hline RS (kg / h) & 2.05 & 2.05 & 2.05 \\
\hline Total D M intake $(\mathrm{kg} / \mathrm{h})$ & 8.30 & 8.30 & 8.30 \\
\hline DM intake (\%BW) & 2.03 & 2.02 & 2.05 \\
\hline DM intake g/kg w & 91.43 & 90.93 & 91.94 \\
\hline Roughage : concentrate ratio $(\mathrm{R} / \mathrm{C})$ & $50: 50$ & $50: 50$ & $50: 50$ \\
\hline \multicolumn{4}{|l|}{ During post-partum period : } \\
\hline CFM $(\mathrm{kg} / \mathrm{h})$ & 5.10 & 5.10 & 5.10 \\
\hline $\mathrm{BH}(\mathrm{kg} / \mathrm{h})$ & 2.55 & 2.55 & 2.55 \\
\hline RS (kg / h) & 2.50 & 2.50 & 2.50 \\
\hline Total DM intake $(\mathrm{kg} / \mathrm{h})$ & 10.15 & 10.15 & 10.15 \\
\hline DM intake (\%BW) & 2.47 & 2.49 & 2.52 \\
\hline DM intake $\left(\mathrm{g} / \mathrm{kg} \mathrm{w}^{0.15}\right)$ & 111.20 & 112.02 & 113.05 \\
\hline Roughage : concentrate ratio $(\mathrm{R} / \mathrm{C})$ & $50: 50$ & $50: 50$ & $50: 50$ \\
\hline
\end{tabular}

\section{Feed conversion :}

The values of feed conversion (feed /milk yield) of Baladi cows fed on the experimental rations during the early lactation are presented in Table ( 8 ). The obtained results indicated that the feed conversion was better with using of two levels of chamomile in cows rations compared to the control group ( unsupplementation). The feed conversion, based on DM was improved by about 6.00 and $8.50 \%$ with the two chamomile treatments (G2 and $\mathrm{G} 3$, respectively) compared with $\mathrm{G} 1$. A similar trend was noticed when feed efficiency was based on TDN where the best was G3 (0.752) followed by G2 (0.767) and lastly the control group ( 0.794$)$. Similar results were observed by El- Garhy et al. (2011) who found that the feed conversion ( based on DM, TDN and DCP) was noticeably better with using some medicinal herbs ( such as mint) in rations of lactation buffaloes. The positive effect of feed conversion efficiency was observed also by El-Nor et al. (2007), Abdelhamid et al. (2011) and Ibrahim et al. (2013) with using some medicinal herbs in ruminant rations. 
Table ( 8 ) : Feed conversion of the experimental rations for milk production.

\begin{tabular}{|l|c|c|c|}
\hline \multirow{2}{*}{ Items } & \multicolumn{3}{c|}{ Groups } \\
\cline { 2 - 4 } & $\mathbf{G}_{\mathbf{1}}$ & $\mathbf{G}_{2}$ & $\mathbf{G}_{3}$ \\
\hline Daily feed intake ( kg / day) : & 10.15 & 10.15 & 10.15 \\
\hline DM intake & 6.83 & 6.98 & 7.08 \\
\hline TDN intake & 0.917 & 0.943 & 0.959 \\
\hline DCP intake & 8.60 & 9.10 & 9.41 \\
\hline Average milk yield ( kg/ day) & & & 1.08 \\
\hline Feed conversion : & 1.18 & 1.11 & 1.752 \\
\hline Kg DM / kg milk & 0.794 & 0.767 & 0.75 \\
\hline Kg TDN / kg milk & 0.107 & 0.104 & 0.102 \\
\hline Kg DCP / kg milk & & &
\end{tabular}

\section{CONCLUSION}

It could be concluded that using of chamomile flowers as a feed additive had a positive effect on improving milk yield and feed utilization efficiency by lactating cows and the improvement was better with the high level of chamomile. Moreover, feeding values and some rumen parameters were also better with chamomile additions. Moreover, no adverse effects of both 2 levels of chamomile were observed on milk composition and blood metabolic parameters.

\section{REFERENCES}

Abdelhamid A. M.; E. I. Shehata and G. A. Maged. (2011). Effect of medical herbs on production of dairy Zaraibi goats . J. Agric. Sci. Mansoura Univ.,2 (11) 493-513.

Abdelhamid, M.A.; Faten F. Abou Ammou; A.E. Abdel-Kalek; M.E. Ahmed; E.I. Shehata; and G.A.Maged (2004). Effect of dietary supplementation with chamomile flowers on caracass characteristics and histology of some organs in Rahmani sheep. J. Agric. Sci. Mansoura Univ.,29(11): 6119- 6135

Abou Akkada, A. R. and K. el-Shazly. (1964). Effect of UREA AND RUMEN PROTOZOAL COUNTS 1305 absence of ciliate protozoa from the rumen on microbial activity and growth of lambs. Appl. Microbiol. 12:384.

Aboul-Fotouh G. E. ; S. M. Allam; A. M. El-Gafarawy; O. A. El-Zalaky; and A. M. Abdel-Hafeez. (2011). Prodctive and reproductive performance of dairy cows fed corn silage without or with some microbial additives. Egyptian J. Nutrition and feeds, 14(3) : 393-408.

Abo-Zeid, E. M. (1986). Medical plants and herbs ( Text book in arabic) Seas house, Beirut.

Ahmed, M. E. ; E. I. Shehata, F. A. Ibrahim, K. M. Aiad, O. A. El-Zalaky. (2008). Milk production and quality of dairy Zaraibi goats fed trifolium alexandrinum (1st cut) silage with some crop residues. Egypt. J of Sheep and Goat Sci. , vol. 3(2), 27-40. 
Ahmed, M. E. and M.E. El-Kholany (2012). Productive performance, some rumen parameters and blood profile of Zaraibi goats fed rations supplemented with chufa tubers during late pregnancy and suckling periods. J. Animal and Poultry Prod., Mansoura Univ., Vol. 3 (12): 537 555 .

Ahmed, M. E., A.M. Abdelhamid, F.F. Abou Ammou, E.S. Soliman, N.M. ElKholy and E. I. Shehata (2001). Response of milk production of Zaraibi goats to feeding silage containing different levels of teosinte and kochia. Egyptian J. Nutrition and Feeds, 4: 141.

Allam, S.M., H.M. El-Hossieny ,A.M. Abdel-Gawad, S.A. El-Saadany and A.M.M. Zeid (1999). Medicinal herbs and plants as feed additives for ruminants. 1-Effect of using some medicinal herbs and plants as feeds additives on Zaraibi goat performance. Egyptian J. Nutrition and Feeds, 2 (Special Issue):349.

AOAC (1980) . Official Methods of Analysis of Association Analytical Chemists. 13th ed Washington, D. C., USA.

Baro, J.A., J.A. Carriedo and F. San Primitivo (1994). Genetic parameters of test day measures for somatic cell count, milk yield and protein percentage of milking ewes. J. Dairy Sci., 77: 2658.

Bedo, S., E. Nikodemusz and K. Gundel (1995). Variations in the yield, composition and somatic cell count of ewes' milk during lactation, Act. Vet Hung. , 43: 463.

Conway, E.F.(1957). Micro diffusion Analysis and Volumetric Error. Rev. Ed. Lock Wood, London.

Duncan, D. (1955). Multiple ranges and multiple F-test. Biometrics,11: 1.

El-Garhy, G. M. ; A. R. Abd El-Rahman and A. M. Abd El-Mola, (2011). Effect of feeding lemon grass by-product on performance of lactating buffaloes. Egyp. J. Nut. And Feed, 14 (3) : 425-431.

EL-Nor, S. A. H. A. ; H. M. Khattab; H. A. Al-Alamy; F. A. Salem and M. M. Abdou (2007). Effect of some medicinal plants seeds in the rations on the productive performance of lactating buffaloes. Intern. J. of Dairy Sci.., 2 (4) : 348-355.

Ibrahim, F.A. K.M.K. Ayad, M.E.Ahmed and M.E. El-Kholany (2013). Effect of using chufa tubers ( Cyprus esculantus L.) in Zaraibi goats diets on the resultant milk and labinah. Egyptian j. of Sheep and Goat Sciences, vol. 8 (1), P : 201-211

Ibrahim, M. R. M;M. E. Ahmed., A. A. El-Shewy, K. M. K. Ayad and K. Etman (2007). Response of lactating goats to rations supplemented with the Egyptian Chufa tubers (Cyprus Esculentus L.). Proc. 10th Egyptian Conf. Dairy Sci. and Techno., 565.

Khanna, T. , F. A. Zaidi and P. C. Tandiya (1993). Central nerves system and analgesic studies on Nigella sativa., Fitoterapia, 64(5):407.

Korting, H. C. , M. Schafer-Korting and H. Hart (1993). Anti-inflammatory activity of hamamleis distillate applied topically to the skin. Influence of vehicle and does. Eur. J. Clin. pharmacol. , 44:315.

Maged, G. A. (2004).Nutritional Studies on Small Ruminants. Master of Agriculture Science. Fac. of Agric., Mansoura Univ., Egypt 
Maged, G. A. (2011). Effect of medical herbs on production of dairy Zaraibi goats . Ph. D. Thesis, Fac. of Agric., Mansoura Univ., Egypt

Mann, C. and E. J. Staba (1986). In herbs, spices and medicinal plants: recent advances in botany, horticulture, and pharmacology. Edited by L. T. Craker and Simon, J.E. . Phoenix, Arizona, Oryx Press. 1:253.

McCartney, D. H. and A. S. Vaage (1994) . Comparative yield and feeding value of barley oat and triticale silages. Can. J. Anim. Sci. p: 91-96.

Mohamed, A. H. B. E. El-Saidy and I. A. El-Seidi (2003). Influence of some medicinal plants supplementation.: 1- On digestability, nutritive value, rumen fermentation and some blood biochemical parameters in sheep. Egyptian J. Nutrition and Feeds, 6:139.

Mostafa T.H., F.A. Elsayed., M.A. Ahmed, and M.A. Elkholany. (2014). Effect of using some feed additives ( TW-probiotics) in dairy cow rations on production and reproductive performance. Egyptian J. Anim. Prod. (2013) $51(1): 1-11$.

NRC, 1988. Nutrient Requirements of Dairy Cattle. 6th rev. ed. National Research Council (U.S.A.). Subcommittee on Dairy Cattle Nutrition. Washington: National Academy of Sciences.

Ody Penelope (1993). The complete medicinal herbal, dorling Kindersley, New York, pg. 47.

Priolo A.; L. Biondi, H. B. Salem and P. Morand-Fehr (2007). Pregnancy toxemia preventation by feeding sarda ewes a spisfic herbal extract compound. Options Mediterraneennes Serie A, Seminaries Mediterraneenns, $74: 407$.

SAS Institute (2003). SAS/STATR User's Guide: statistics. Ver. 9.1, SAS Institute Inc., Cary, NC, USA.

Schultz, T.A. and E. Schultz (1970). Estimation of rumen microbial nitrogen by three analytical methods. J. Dairy Sci , 53:781.

Shehata, E.E.; F.H. Abd El-Rasoul; F.F. Abou Ammou, M.E.Ahmed and A. M. Abdel-Gawad ( 2007). Effect of feeding some medicinal herb, Chamomile flowers, on some productive performance of Egyptian Zaraibi does and their new porn kids. Egyptian J. of Sheep and Goat Sci. 2(2);111-120.

Shehata, E.E.; F.H. Abd El-Rasoul; M.E.Ahmed, F.F. Abou Ammou and R.ElAhwall (2004). Effect of feeding a medicinal herb, chamomile flower on production and hygiene of goat milk production. Egypt. J. Nutr and Feeds, $7: 109$.

Shwereb, A. M. (2012). Effect of different levels of plam kernel cake in lactating cow diets. Egyptian J. Nutrition and feeds , 15(3) : 435-449.

Shwereb, A. M. ; M. S. Khalel; A. A. Hassan; Amany a. Khayyal and M. H. Yacout. (2014). The act of Eucalyptus leaves as a source of essential oils on dairy cows performance. Egyp. J. Nutr. And feeds, 17 (2) : 207224.

Tawfik, S.A, M.E. Ahmed, E.I. Shehata and O.B. EL-Gazzar (2005). Effect of adding chamomile flowers to aflatoxins contaminated diet on growth performance, rumen parameters and some blood components of growing lamb's .4th Int. Sci. Conf., Mansoura. 251. 
Thakur, S. S. ; A. K. Tyagi and K. K. Singhal. (2006), Effect of a commercial herbal feed supplement on the performance of lactating cows, Indian Journal of Animal Nut. 23 (4): 244-246.

Warner, A.C.I. (1964). Production of volatile fatty acids in the rumen, methods of measurements. Nutr. Abst. \& Rev., 34: 339.

Zeedan, Kh. I. I. and Abdel-Latif, M. A. (2013). Improvement of immunological and productive performance for buffalo by using some natural additive. 2- using levels of crude papaya (Carica papaya) latex on productive and reproductive performance in Egyptian buffaloes cow. Egyptian J. Nut. and Feeds $16(3)$ : 461-477

Zeid, A.M. (1998). Effect of using medicinal plants on goats performance. Ph. D. Thesis, Fac. of Agric., Cairo Univ., Egypt.

Zeid ,A.M. and M.E. Ahmed (2004). Productive performance of Zaraibi goats fed rations containing some medicinal herbs. J. Agric. Sci. Mansoura Univ. 29 (2): 595-608.

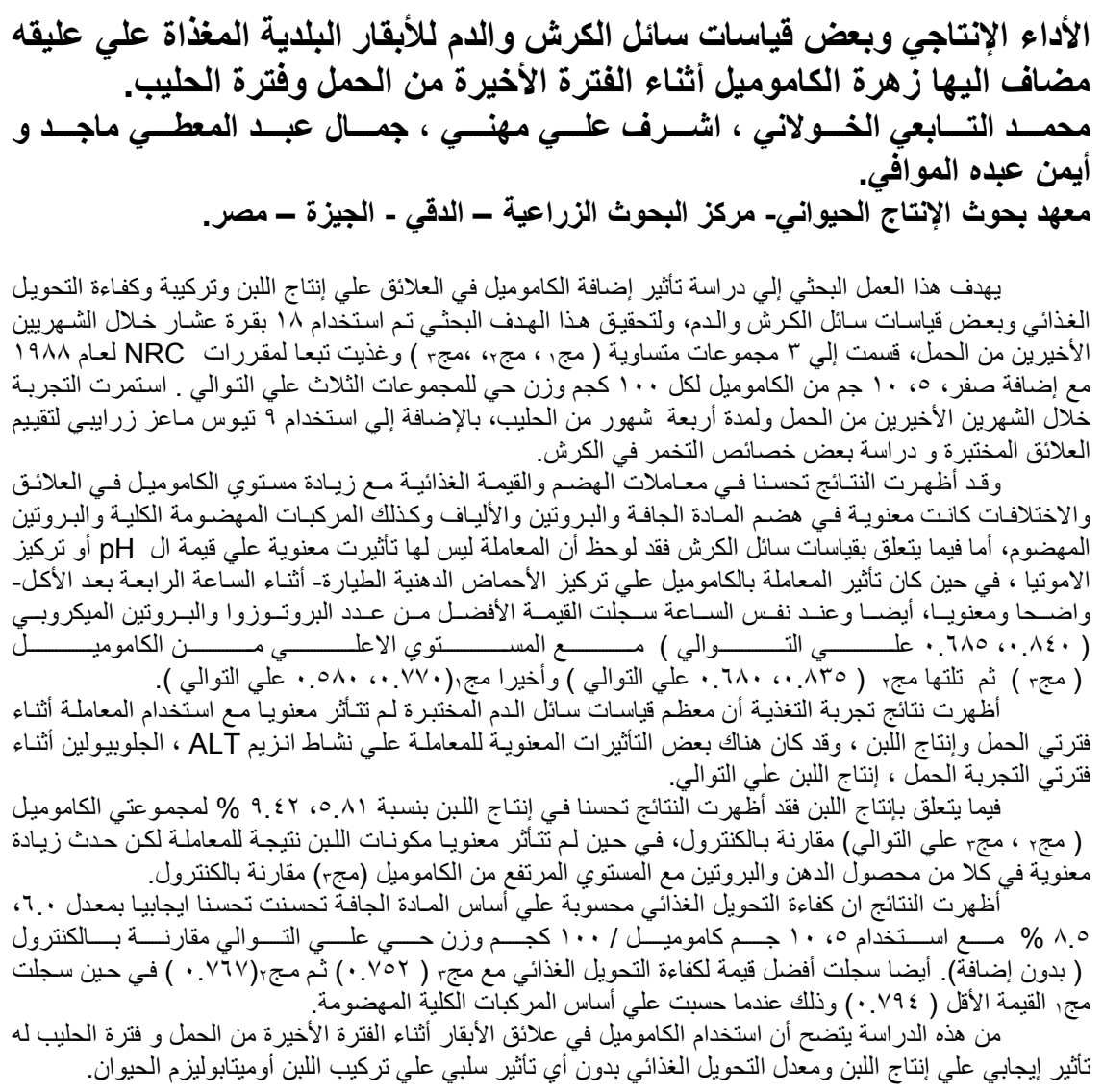


El-Kholany, M. E. et.al 